\title{
Scion Image Analysis in rocks of the hanging wall and foot wall of the MCT, central Nepal
}

\author{
Kamala Kant Acharya* and Bernhard Grasemann \\ Department of Geodynamics \& Sedimentology, Structural Processes Group, Vienna University, AUSTRIA \\ *For correspondence, email: Acharyk4@univie.ac.at
}

In central Nepal, the Kathmandu Crystalline Thrust Sheet comprises rocks of the Higher Himalayan Crystalline, overlying lower metamorphic grade rocks of the Nawakot Complex, separated by the Main Central Thrust (MCT). All these rocks, which are sometimes combined in the 'Kathmandu Nappe', have been folded to form the NW-SE trending, essentially upright Mahabharat Synform. A public downloading software Scion imaging has been used to quantitative image analyse of thin sections from the area especially in the vicinity of the thrust. Scion Image is an image processing and analyzing program (Scioncorp.com).

Images of seven thin sections from different parts of central Nepal were analysed using Scion Image. These thin sections were prepared from the three samples collected from the hanging wall i.e. Kathmandu Complex rocks and four samples from the foot wall i.e. Nawakot Complex rocks of the MCT. The ellipse major axis, ellipse minor axis, and orientation of the ellipse major axis of quartz and feldspar grains were measured using this software from the thin sections. The ellipticity and Bretherton shape index were calculated from the obtained values.

The analysis shows that, rocks of the Nawakot Complex (Lesser Himalaya) record a monoclinic symmetry while rocks of the Kathmandu Complex (Higher Himalaya) record an orthorhombic symmetry. In one sample collected from the thrust zone of the MCT, quartz grains show orthorhombic while feldspar grains show monoclinic symmetry. In all the samples feldspar behave as a rigid particle whilst quartz grains show evidence of ductile deformation. Flattening and elongation of quartz grains is strong parallel to the foliation. Rocks of the Kathmandu Complex and of the MCT thrust zone show higher rheological role of quartz than in rocks of the Nawakot Complex. Some rocks of the Kathmandu and Nawakot Complex shows asymmetry indicating non-coaxial deformation. Other possible indicators of non-coaxial deformation, such as extensional crenulation cleavage, S-C shear bands, porphyroclasts with asymmetric pressure shadows and porphyroblasts with curved inclusion trails have also been observed in thin-sections. The strain partitioning between individual phases, typical of lower metamorphic grade rocks such as the chlorite grade Nawakot Complex diminishes as the metamorphic grade increases to garnet and biotite grade in the Kathmandu Complex and deformation becomes more nearly homogenous. In the sample from MCT zone, where both quartz and feldspar grains have been analysed, feldspars show a higher ellipticity than quartz. The average ellipticity of quartz in all of these rocks is more or less similar but in feldspar rocks of the Kathmandu Complex shows higher average ellipticity than rocks of the Nawakot Complex. Comparatively feldspar grains show higher variation in ellipticity and Bretherton Shape Index than that of quartz. In these rocks, shear sense indicators show both pure shear flattening fabrics and non-coaxial south-directed simple shear fabrics.

From these observations, it can be said that rocks of both the hanging wall and footwall show a significant pure shear component early in the deformation and simple shear component during exhumation. Therefore, the MCT can be characterized as Stretching Fault Thrusting (Means 1989), where wall rocks lengthen perpendicular to the shear direction, and MCT partially acted as Stretched Fault Thrust. 